М.Б. Кравченко, канд. техн. наук

Одесская национальная академия пищевых технологий, ул. Канатная, 112, г. Одесса, 65039

e-mail:kravtchenko@i.ua

ORCID: http://orcid.org/0000-0002-9310-2166

\title{
ТЕРМОБИОНИКА. АКТИВНАЯ ТЕПАОВАЯ ЗАЩИТА ЖИВЫХ ОРГАНИЗМОВ И ВОЗМОЖНОСТИ ЕЕ ПРИМЕНЕНИЯ В ТЕХНИКЕ
}

\begin{abstract}
Теплокровные организмы обладают эффективной системой поддержания температуры тела. Для выяснения особенностей терморегуляции живых организмов предложена математическая модель теплообмена живой ткани с окружающей средой. По справочным данным о средней температуре кожного покрова и объёме крови, перекачиваемой сердцем человека, произведена настройка разработанной математической модели. Показано, что путём регулирования интенсивности кровообращения в коже и подкожных тканях, живые организмы могут изменять кажущуюся теплопроводность их тканей, по крайней мере, на два порядка. На основании полученных количественных результатов объяснен феномен хождения по раскалённым уалям. Рассмотрены перспективы применения активной тепловой защиты в криогенной и аэрокосмической технике. Оценочные расчеты показывают, что упорядоченная теплоизоляционная структура, имитирующая живую ткань, имеет эквивалентную теплопроводность 0,014 Bm/ (мК) при скорости циркулирующего в ней азота 2,6 мм/с. B рассмотренном примере расход энергии на поддержание циркуляции газа имеет величину порядка 1 мВт на квадратный метр теплоизолируемой поверхности.
\end{abstract}

Ключевые слова: Терморегуляция. Живая ткань. Теплопроводность. Теплоизоляция. Криогенные баки. Активная тепловая защита. Космический аппарат.

\section{BBEAЕHИЕ}

Известно, что живые организмы обладают изощренной системой терморегуляции. В особенности это относится к теплокровным животным. Ярким примером удивительной способности теплокровных организмов поддерживать практически постоянную температуру тела являются морские млекопитающие, которым удается сохранять практически постоянную температуру внутри тела как в ледяной воде, так и на поверхности земли, прогреваемой солнечными лучами.

Ещё более впечатляющий пример способности живого организма поддерживать температуру тела в невероятно экстремальных условиях - является способность некоторых людей ходить босиком по раскаленным углям, не получая при этом ожогов. В данном случае речь идет о людях, которым в условиях научного эксперимента удаётся пройти десятки метров по горящим углям с температурой $400-500{ }^{\circ} \mathrm{C}$.

В настоящее время высказываются различные гипотезы для объяснения феномена хождения человека по огню. Но все эти гипотезы имеют качественный характер. Убедительное объяснение феномена хождения по огню возможно только на основе математической модели, способной дать конкретные количественные результаты.

Объяснение этих феноменальных возможностей людей нужно искать в системе регулирования кажущейся теплопроводности кожи и тканей, расположен- ных непосредственно под кожей. Как будет показано ниже, путём регулирования интенсивности кровообращения в коже и подкожных тканях живые организмы могут изменять кажущуюся их теплопроводность, по крайней мере, на два порядка.

Конструкции, обладающие подобными свойствами, востребованы в технике и, в частности, в технике низких температур.

\section{2. МАТЕМАТИЧЕСКАЯ МОАЕАЬ ПЕРЕНОСА ТЕПАА В ЖИВОЙ ТКАНИ}

На рис. 1 приведена схема, иллюстрирующая механизм переноса тепла в живой ткани.

Кровь, циркулирующая в многочисленных капиллярах, которыми пронизаны ткани, переносит не только кислород и питательные вещества, но и тепло. Артериальная кровь, движущаяся к поверхности кожи, обозначена красными линиями, а венозная кровь, движущаяся в обратном направлении, - синими.

Расчётная схема для математической модели теплообмена в живой ткани приведена на рис. 2.

В качестве модельного объекта для одномерной модели теплообмена живой ткани принято плоское ребро, продольная теплопроводность которого равна теплопроводности ткани в отсутствии кровообращения (теплопроводности мертвой ткани). Ребро омывается потоком жидкости с теплопроводностью крови. 